\title{
Participation of Stakeholders at Different Stages of Technology Assessment, Refinement and Validation under ATMA
}

\author{
Reena Rawal* and Seema Rani \\ Department of Extension Education and Communication Management, CCS Haryana \\ Agricultural University, Hisar-125004, India \\ *Corresponding author
}

\begin{tabular}{|c|c|}
\hline & A B S T R A C T \\
\hline & \multirow{4}{*}{$\begin{array}{l}\text { Aim of the study is to determine the stakeholders' perception about the characteristics of } \\
\text { technology transfers to farmers and their participation at different stages of technology } \\
\text { assessment, refinement and validation under ATMA, } 18 \text { stakeholders of ATMA were } \\
\text { selected randomly. Findings of the study revealed that stakeholders have more awareness } \\
\text { about the technology generation/refinement /validation activities in cereals crops. The } \\
\text { maximum participation of ATMA stakeholders was found in identification of research } \\
\text { issue and implementation of the farmer participatory research (FPR). Stakeholders of } \\
\text { ATMA perceived that technology transferred to the farmers with some important } \\
\text { characteristics which were their designed for improving farmers over all income, need } \\
\text { based, timely, affordable by the farmers, at the doorstep of farmers, easy to operate and } \\
\text { acceptable to farming community. }\end{array}$} \\
\hline $\begin{array}{l}\text { ATMA, Farmer } \\
\text { participatory } \\
\text { research (FPR) }\end{array}$ & \\
\hline Article Info & \\
\hline $\begin{array}{l}\text { Accepted: } \\
\text { 07 May } 2019 \\
\text { Available Online: } \\
\text { 10 June } 2019\end{array}$ & \\
\hline
\end{tabular}

\section{Introduction}

Agriculture is the backbone of the Indian economy which plays the most decisive role in the socio-economic development of the country. Agriculture is the most important occupation for most of the Indian families. It employs more than 50 per cent of the total workforce. In India, agriculture contributes about $17-18 \%$ of the GDP (Economic Survey 2017-18) and ten percent (10\%) of total exports.

We live in a world where technology is at the heart of our everyday lives. Currently farmers choose crops on the basis of the trends of the last season. Technology can assist them in making right growing choices by carefully analyzing demand, pricing and fluctuations in weather conditions. This will create a better balance between supply and demand.

A research unit in each district project assigned the responsibility of refinement and validation location specific and system based technology for each agro climatic zone. As an institution Technology assessment, refinement and validation are an integral part of ATMA. The activities of ATMA technology assessment, refinement, and transfer, aiming to bridge the gap between the technologies developed at research stations and its adoption at field level. To overcome the problem of to generate technology for 
specific area and specific farmers, different stakeholders of ATMA participate at the different stages of technology assessment, refinement and validation.

The main objectives of this study includes awareness about the technology generation/refinement/validation activities undertaken by research system under ATMA and also Participation of different stakeholders at different stages of technology assessment, refinement and validation

\section{Materials and Methods}

To determine the participation, awareness about technology assessment, refinement, 18 stakeholders of ATMA were selected randomly from Gurugram division of Haryana. The data were collected personally with the help of questionnaire. The data were tabulated and analyzed to draw the meaningful interferences.

\section{Results and Discussion}

\section{Socio-economic profile of the stakeholders under ATMA}

A look at the Figure 1 revealed that more than one fourth $(27.77 \%)$ of stakeholders were Agriculture Development Officer followed by Block Agriculture Officers (22.22\%), Agriculture Technology Manager (16.67\%), Deputy Director Agricultural and SubDivisional Agriculture Officer with same percentage (11.11\%), Block Technology Manager and Technical Assistance (5.56\%).

The results in the Figure 2 reveled that majority of the stakeholders $(55.56 \%)$ belonged to other backward caste followed by schedule caste $(27.78 \%)$ and general caste (16.67\%).

Most of the of stakeholders $(61.11 \%)$ had less than 10 years of experience followed by 22.22 per cent who had 10-20 years of experience and 16.67 percent who had more than 20 years of experience and had rich experience about ATMA and its activities (Fig. 3).

More than fifty percent of stakeholders (61.115) earned 2 to 4 lakh annually followed by 38.89 percent who earned 2 to 4 lakh (Fig. 4).

\section{Awareness about the technology generation/refinement/validation activities undertaken by research system in the following areas under ATMA}

The responses of stakeholders on awareness about technology generation, refinement and validation activities in 21 items including crops, vegetables, fruits, flowers, diary, poultry etc. have been obtained. The stakeholders had found to have relatively better (+ than average) awareness of technology generated, refined and validated in case of cereals, pulses, oil seeds, vegetables, fruits integrated nutrient management, integrated pest and diseases management, integrated weed management, water management, soil management, vermicomposting, mushroom, post-harvest and value addition and agriculture implements whereas lack awareness (- than average) in case of spices, flowers, dairy, poultry, goatery, apiary, pisciculture. The result indicated that poor awareness areas did not have much research either in the agenda or not received demand (Table 1).

\section{Participation of different stakeholders at different stages of technology assessment, refinement and validation}

Data related to participation of farmers at different stages of technology assessment, refinement and validation revealed that identification of research issue and implementation of the farmer participatory research (FPR) trial was ranked I with highest 
mean (2.28) followed by monitoring and evaluation of the trials (2.22) ranked II, designing the FPR trial with indication treatments and as prioritizing the issues with the same mean (2.17) ranked III and planning the FPR trial including selection of farmer and recommendation of the findings with same mean (2.11) ranked IV.

The data further reveals that maximum participation of extension system was found in identification of research issue (2.44) which was ranked I followed by planning the farmer participatory research (FPR) trial including selection of farmer (2.39) ranked II, prioritizing the issues (2.33) ranked III, monitoring and evaluation of the trials (2.28) ranked IV and designing the FPR trial with indication treatments, implementation of the FPR trial and recommendation of the findings with the same mean ranked $\mathrm{V}$.

The table 2 also highlights participation of research system at different stages of technology assessment, refinement and validation. Result found that prioritizing the issues (2.33) was ranked I followed by identification of research issue, designing the farmer participatory research (FPR) trial with indication treatments and planning the FPR trial including selection of farmer with the same mean (2.28) ranked II, implementation of the FPR trial (2.22) ranked III and monitoring and evaluation of the trials (2.17) ranked IV (Fig. 5 and 6).

Table.1 Awareness about the technology generation/refinement/validation activities undertaken by research system under ATMA $n=18$

\begin{tabular}{|l|l|l|l|l|}
\hline Sr. No & Commodity / Crop & Mean score & Rank & + than average \\
\hline $\mathbf{1}$ & Cereals & 2.83 & I & + \\
\hline $\mathbf{2}$ & Pulses & 2.78 & II & + \\
\hline $\mathbf{3}$ & Oilseeds & 2.83 & I & + \\
\hline $\mathbf{4}$ & Spices & 1.56 & XII & - \\
\hline $\mathbf{5}$ & Vegetable & 2.17 & IX & - \\
\hline $\mathbf{6}$ & Fruits & 2.29 & VII & - \\
\hline $\mathbf{7}$ & Flowers & 1.78 & X & - \\
\hline $\mathbf{8}$ & Integrated nutrient management & 2.56 & V & + \\
\hline $\mathbf{9}$ & Integrated pest and diseases management & 2.56 & V & + \\
\hline $\mathbf{1 0}$ & Integrated weed management & 2.61 & IV & + \\
\hline $\mathbf{1 1}$ & Water management & 2.56 & V & + \\
\hline $\mathbf{1 2}$ & Soil management & 2.56 & V & + \\
\hline $\mathbf{1 3}$ & Dairy & 1.67 & XI & - \\
\hline $\mathbf{1 4}$ & Poultry & 1.56 & XII & - \\
\hline $\mathbf{1 5}$ & Goatery & 1.50 & XIII & - \\
\hline $\mathbf{1 6}$ & Mushroom & 2.23 & VIII & - \\
\hline $\mathbf{1 7}$ & Vermicomposting & 2.72 & III & + \\
\hline $\mathbf{1 8}$ & Apiary & 1.39 & XV & - \\
\hline $\mathbf{1 9}$ & Pisciculture & 1.44 & XIV & - \\
\hline $\mathbf{2 0}$ & Agril. implement & 2.72 & III & + \\
\hline $\mathbf{2 1}$ & Post-harvest and value addition & 2.57 & VI & - \\
\hline Average & Mean Score & 2.15 & & \\
\hline & & & & \\
\hline
\end{tabular}


Table.2 Participation of different stakeholders at different stages of technology assessment, refinement and validation $\mathrm{n}=18$

\begin{tabular}{|c|c|c|c|c|c|c|c|}
\hline \multirow[t]{3}{*}{ Sr. No } & \multirow[t]{3}{*}{ Stages } & \multicolumn{6}{|c|}{ Participation of different stakeholders } \\
\hline & & \multicolumn{2}{|c|}{ Farmers } & \multicolumn{2}{|c|}{$\begin{array}{l}\text { Extension } \\
\text { system }\end{array}$} & \multicolumn{2}{|c|}{$\begin{array}{l}\text { Research } \\
\text { system }\end{array}$} \\
\hline & & MS & Rank & MS & Rank & MS & Rank \\
\hline 1 & Identification of research issue & 2.28 & I & 2.44 & I & 2.28 & II \\
\hline 2 & Prioritizing the issues & 2.17 & III & 2.33 & III & 2.33 & I \\
\hline 3 & $\begin{array}{l}\text { Designing the FPR trial with } \\
\text { indication treatments }\end{array}$ & 2.17 & III & 2.06 & $\mathrm{~V}$ & 2.28 & II \\
\hline 4 & $\begin{array}{l}\text { Planning the FPR trial including } \\
\text { selection of farmer }\end{array}$ & 2.11 & IV & 2.39 & II & 2.28 & II \\
\hline 5 & Implementation of the FPR trial & 2.28 & I & 2.06 & $\mathrm{~V}$ & 2.22 & III \\
\hline 6 & $\begin{array}{l}\text { Monitoring and evaluation of the } \\
\text { trials }\end{array}$ & 2.22 & II & 2.28 & IV & 2.17 & IV \\
\hline 7 & Recommendation of the findings & 2.11 & IV & 2.06 & $\mathrm{~V}$ & 2.22 & III \\
\hline
\end{tabular}

Maximum Obtainable Score $=3.00$

Table.3 Perception of stakeholders about the characteristics of technology transferred to farmer $\mathrm{n}=18$

\begin{tabular}{|l|l|l|l|}
\hline Sr. No & Technology & Mean score & Rank \\
\hline $\mathbf{1}$ & Need based & 4.28 & II \\
\hline $\mathbf{2}$ & Timely & 4.28 & II \\
\hline $\mathbf{3}$ & Understandable language & 4.11 & IV \\
\hline $\mathbf{4}$ & At the doorstep of farmer & 4.17 & III \\
\hline $\mathbf{5}$ & Compatible with existing farming system & 4.06 & V \\
\hline $\mathbf{6}$ & Affordable by the farmers & 4.17 & III \\
\hline $\mathbf{7}$ & Having high rate of productivity & 3.94 & VI \\
\hline $\mathbf{8}$ & Easy to operate & 4.17 & III \\
\hline $\mathbf{9}$ & Acceptable to farming community & 4.17 & III \\
\hline $\mathbf{1 0}$ & $\begin{array}{l}\text { Designed for improving overall income of } \\
\text { the farmer }\end{array}$ & 4.39 & I \\
\hline
\end{tabular}


Fig.1: Distribution of Stakeholdrs as per their designation
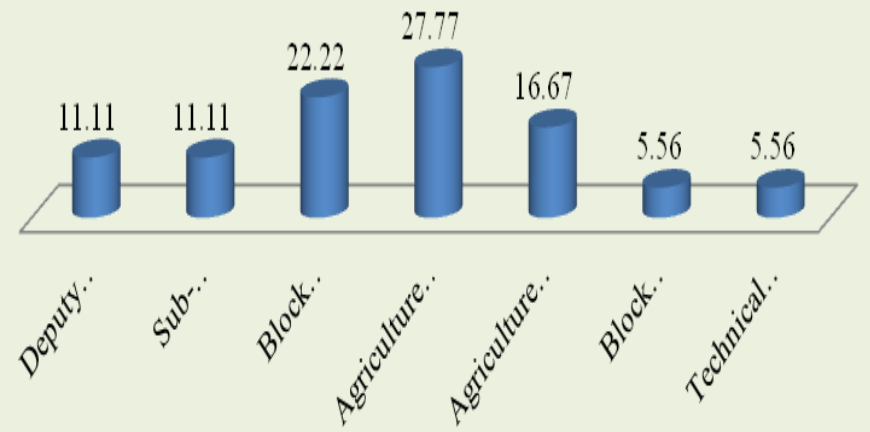

\section{Fig.2: Distributionn of Stakeholders accorting to theis caste}

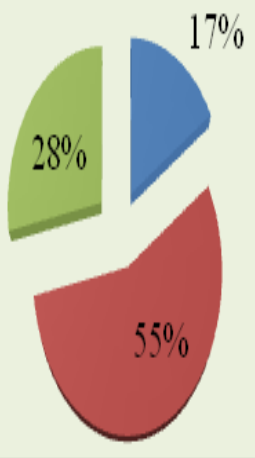

- General

- Other Backward Caste (OBC)

-Scheduled caste/Scheduled tribe(SC/ST)

Fig.3: Distribution of Stakeholders according to their years of experience

$$
\square<10 \text { years } \quad 10-20 \text { years } \quad>20 \text { years }
$$

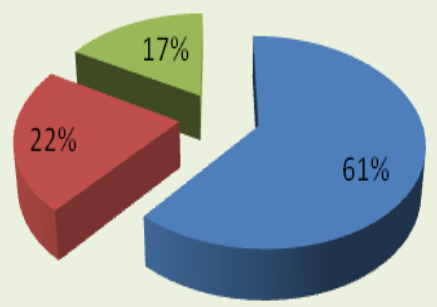




\section{Fig.4: Distribution of the Stakeholders accortding to} the annual income

$$
\text { -2-4 lakh } \quad \text { 4-6 lakh }
$$

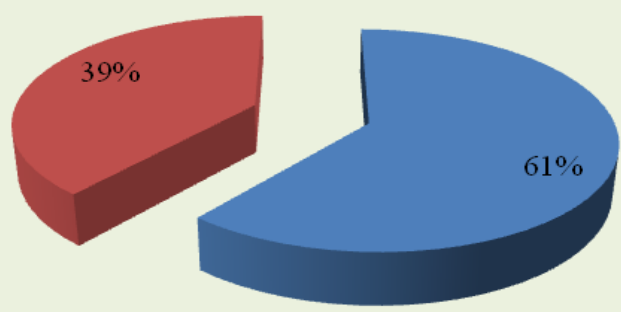

Fig. 5: Awareness about the technology

generation/refinement/validation activities undertaken by research sy stem under AT MA
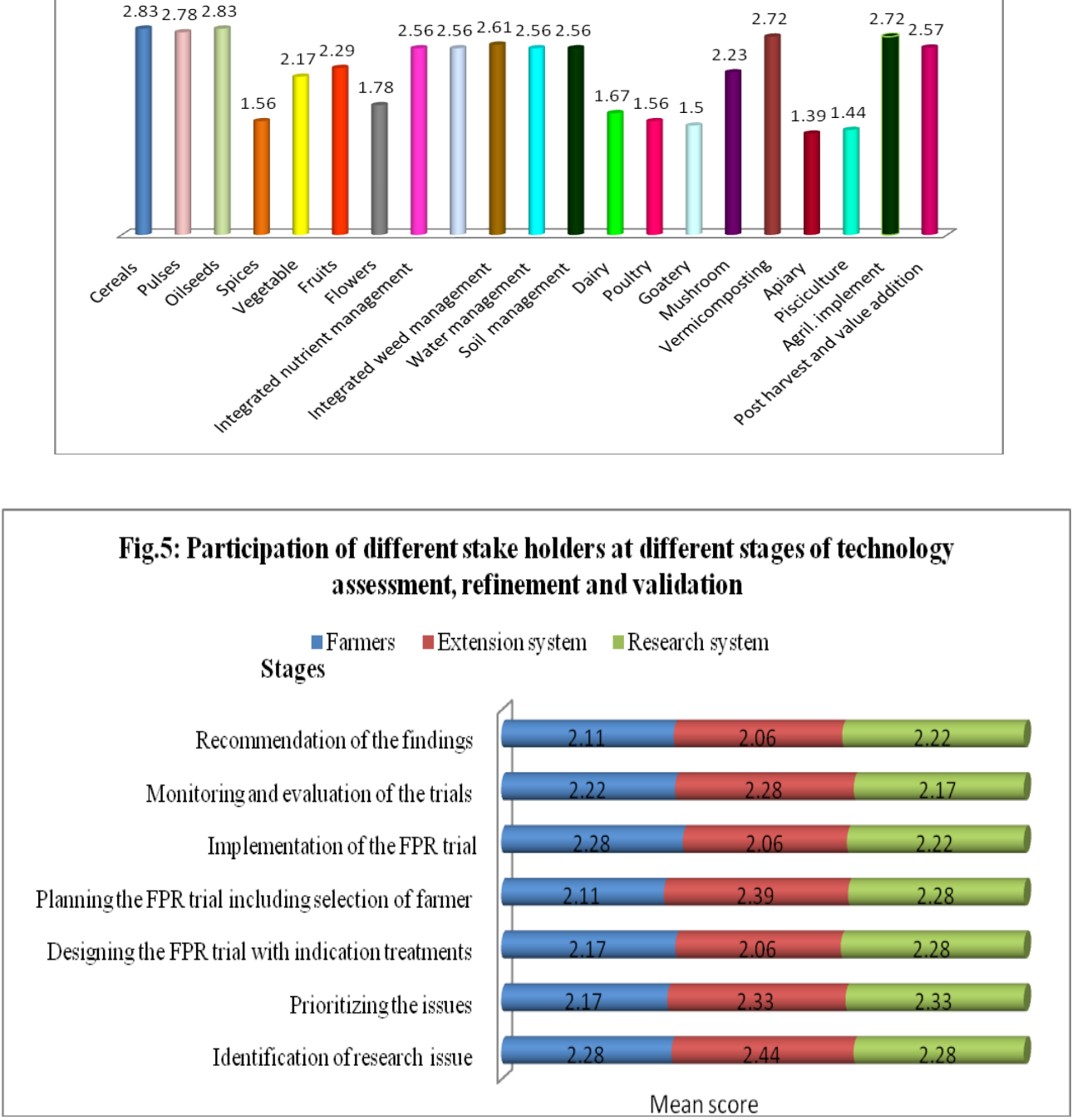
Perception of stakeholders about the characteristics of technology transferred to farmer

As indicated in the table 3 out of 10 characteristics of technology which have been transferred to farmers, designed for improving overall income of the farmer was on top with highest mean score ranked I followed by need based and timely with same mean (4. 28) ranked II, technology at the door step of the farmers, affordable for the farmers and acceptable to farming community with same mean (4.17) ranked III, understandable language and high rate of productivity with the same mean (4.11) ranked IV and compatible with existing farming system (4.06) ranked V.

On the basis of the findings, it can be concluded that the maximum participation of farmers at identification of the research issue and implementation the FPR trail. Extension system had also maximum participation identification of the research issue whereas research system had maximum participation in prioritizing the issue. Design of technology for improving overall income of the farmer was most important characteristics of technology followed by need based, timely, technology at the door step of the farmers, affordable for the farmers, acceptable to farming community, understandable language, high rate of productivity and compatible with existing farming system. Stakeholders had maximum awareness about technology in the cereal crops.

\section{References}

India economic survey 2018: Farmers gain as agriculture mechanisation speeds up, but more R\&D needed https://www.financialexpress.com/bud get/india-economic-survey-2018-forfarmers-agriculture-gdp$\mathrm{msp} / 1034266 /$

Directorate of Agriculture, ATMA Schemes. https://dag.gujarat.gov.in/atmaschemes.htm

Liddell, Henry George; Scott, Robert (1980). A Greek-English Lexicon (Abridged Edition). United Kingdom: Oxford University Press. i

\section{How to cite this article:}

Reena Rawal and Seema Rani. 2019. Participation of Stakeholders at Different Stages of Technology Assessment, Refinement and Validation under ATMA. Int.J.Curr.Microbiol.App.Sci. 8(06): 736-742. doi: https://doi.org/10.20546/ijcmas.2019.806.087 